Електронне наукове фахове видання «Адаптивне управління: теорія і практика. Серія «Педагогіка»

Випуск 9(17), 2020

УДК 37.062

https://doi.org/10.33296/2707-0255-9(17)-23

https://orcid.org/0000-0002-9213-5556

СОБЧЕНКО ТЕТЯНА,

кандидат педагогічних наук, доцент,

доцент кафедри педагогіки

Харківського національного

педагогічного університету імені

Г.С. Сковороди, м. Харків, Україна

\title{
ЗМІШАНЕ НАВЧАННЯ ЯК ЗАСІБ АКТИВІЗАЦЇ̈ АДАПТИВНИХ ПРОЦЕСІВ У ВИЩІЙ ПЕДАГОГІЧНІЙ ОСВІТІ
}

Анотація. Статтю присвячено організації змішаного навчання у закладах вищої педагогічної освіти. Акцентовано увагу на висвітлені можливості реалізації змішаного навчання як засобу активізації адаптивних процесів у вищій педагогічній освіті.

Зазначено, що активізація адаптивних процесів $є$ наразі затребуваною у сьогоденні. У статті здійснено аналіз праць вітчизняних та зарубіжних науковців із визначеної проблеми дослідження.

У змісті статті презентовано власний досвід організації змішаного навчання на прикладі вивчення педагогічних дисциплін майбутніми вчителямифілологами у Харківському національному педагогічному університеті імені Г.С. Сковороди та розкрито його адаптивний характер. Розглянуто способи організації освітнього контенту, створення диференційованих завдань, здійснення активізації навчально-пізнавальної діяльності та мотивації студентів. Увагу зосереджено також на організації різних видів контролю (поточного, підсумкового) навчально-пізнавальної діяльності, як важливої складової адаптивного процесу навчання.

Звернено увагу на те, ще у організації змішаного навчання важливим моментом $\epsilon$ вибір моделей. Моделі «Перевернутого класу», «Ротації за станціями» $є$ найбільш зручними та доцільними при викладанні педагогічних дисциплін.

У статті наведено конкретні приклади використання інформаційнокомунікативних та хмарних технологій у процесі вивчення педагогічних дисциплін здобувачами гуманітарних спеціальностей.

Узагальнено можливості змішаного навчання як засобу активізації адаптивних процесів у вищій педагогічній освіті, зокрема реалізація

\footnotetext{
(C) Українська інженерно-педагогічна академія

(C) ГО «Школа адаптивного управління соціально-педагогічними системами»

(C) Собченко Т.
} 
Електронне наукове фахове видання «Адаптивне управління: теорія і практика. Серія «Педагогіка»

індивідуального підходу до особистості здобувача, визначено переваги та слабкі сторони.

Зазначено, що подальші розвідки досліджень будуть спрямовані на теоретичне обгрунтування дидактичної системи змішаного навчання студентів гуманітарних спеціальностей у закладах вищої педагогічної освіти.

Ключові слова. Змішане навчання, адаптивне навчання, здобувачі вищої освіти, педагогічні дисципліни.

Вступ. Інтенсивне пришвидшення інформатизації та технізації сучасного світу охопило всі сфери людського життя. Не виключенням стала і система освіти, зокрема іiї інформатизація. На перший план виходить орієнтація у потоці інформації, яка зростає 3 кожним днем, здатність до самонавчання та саморозвитку, оволодіння сучасними інформаційно-комунікаційними технологіями, що з одного боку, є необхідною вимогою часу, а 3 іншого, відкриває нові перспективні можливості. Адже вільний доступ до будь-якої інформації, орієнтир на нові цінності, навчання за різних умов та обставин, адаптація до соціальних змін спонукає, навіть змушує, формувати затребувані особисті та професійні компетентності.

Також досить вагомі корективи у систему освіти внесла пандемія, спричинена короновірусом, яка спонукала до спонтанного введення, через карантинні обмеження, дистанційної та змішаної форми навчання у закладах освіти усіх ланок. 3 огляду на це, проблема адаптивних процесів у вищій педагогічній освіті є наразі актуальною та вимагає негайного вирішення.

Актуальні наукові досягнення та аналіз проблем. Сьогодні у літературних джерелах питанням адаптивного навчання приділяється значна увага. Дослідження закономірностей прояву та структури адаптивних процес $\epsilon$ предметом наукового пошуку вітчизняних та зарубіжних учених. Так, у науковій праці Ю. Бунтури, О. Канищева, М. Вовк, І. Лютенко адаптивне навчання розглянуте як система, яка здатна надати стати у нагоді кожному студентові для досягнення оптимально рівня його інтелектуального розвитку [3]. В. Бондар, Т. Опалюк, О. Цвєтаєва, О. Знанецька розглядають адаптивне

(C) ГО «Школа адаптивного управління соціально-педагогічними системами»

(C) Собченко T. 
Електронне наукове фахове видання «Адаптивне управління: теорія і практика. Серія «Педагогіка» Випуск 9(17), 2020

навчання як партнерську (компетентнісну) взаємодію між викладачами та здобувачами вищої освіти $[1,7,10]$, принципи адаптивного навчання, серед яких диференціації, індивідуалізації, тощо виділяє В. Пішванова [8].

Слід відмітити, що для нашого дослідження вагомий інтерес представляє монографія (колективна) за редакцією В. Бондаря, де розкрито наукові основи i способи підготовки майбутніх учителів до адаптивного навчання у закладах загальної середньої освіти, вперше системно розкрито концептуальні засади та способи реалізації адаптивного навчання майбутніх учителів нової української школи [1]. Не менш важливими є напрацювання Г. Сльникової у цьому напрямі: реалізація адаптивних технологій навчання у вищій школі [4], розгляд STEM-OCВITИ в контексті адаптивного навчання [5].

Астахова, М., Лапко, Д. досліджують питання адаптації до дистанційної освіти у різних країнах у середніх закладах освіти [2].

Не дивлячись на розмаїття напрямів вивчення адаптивного навчання у закладах освіти усіх ланок, на сьогоднішній день питання активізації адаптивних процесів у вищій педагогічній освіти через змішане навчання не було предметом спеціального дослідження науковців.

Формулювання мети статті висвітлити можливості використання змішаного навчання для активізації адаптивних процесів у вищій педагогічній освіті.

Виклад основного матеріалу. На основі аналізу наукових джерел $[1,3,4,5,7]$ нами сформульовано робоче визначення поняття «адаптивного навчання». Адаптивне навчання ми розглядаємо як організацію освітнього контенту з можливістю створення оптимальних умов для опанування змістом освіти кожним здобувачем вищої освіти, незалежно від його навчальних та індивідуальних можливостей, особистих здібностей.

Так, метою «Концепції розвитку педагогічної освіти» (виконавче розпорядження Міністерства освіти і науки України №776 від 16 липня 2018
(C) Українська інженерно-педагогічна академія
(C) ГО «Школа адаптивного управління соціально-педагогічними системами»
(C) Собченко T. 
Електронне наукове фахове видання «Адаптивне управління: теорія і практика. Серія «Педагогіка»

Випуск 9(17), 2020

року) є вдосконалення системи педагогічної освіти для створення бази підготовки педагогічних працівників нової генерації [6].

Здійснення якісної професійної підготовки майбутніх вчителів у закладах педагогічної вищої освіти вимагає суттєвих змін підходу до здійснення ефективної організації освітнього процесу. В опублікованій раніше авторській статті авторській статті зазначено, що, це може забезпечити:

- наявність команди фахівців, професіоналів, які мають здійснювати якісну підготовку здобувачів вищої освіти із урахуванням запитів «нової української школи» та сучасних освітніх викликів, а також з орієнтиром на нові перспективні професії, зокрема, «андрагог», «тьютор», «модератор», «фасилітатор», «менеджер електронного навчання», «асистент вчителя» тощо;

- зміна підходу до здійснення ефективної організації освітнього, а саме: коригування та оновлення змісту навчальних програм, удосконалення форм та методів навчання, використання гейміфікації, розробка та впровадження вибіркових навчальних дисциплін із урахуванням запитів стейкхолдерів, застосування дуального навчання тощо [9].

Це вимагає зосередження уваги на адаптивних процесах у вищій педагогічній освіті. Ефективним засобом активізації адаптивних процесів у закладах вищої педагогічної освіти $€$ використання змішаного навчання.

Враховуючи, що таку практику було накопичено у Харківському національному педагогічному університеті імені Г.С. Сковороди, розкриємо власний досвід використання змішаного навчання на прикладі вивчення педагогічних дисциплін майбутніми вчителями-філологами, оскільки авторка $\epsilon$ викладачем кафедри педагогіки та працює на українському мовнолітературному факультеті імені Г.Ф. Квітки-Основ'яненка.

Так, здобувачі першого освітнього (бакалаврського) рівня вищої освіти, починаючи з першого курсу, вивчають комплексну дисципліну «Педагогіку». Відразу слід зазначити, що з переходом на дистанційну (згодом на змішану)

\footnotetext{
(C) Українська інженерно-педагогічна академія

(C) ГО «Школа адаптивного управління соціально-педагогічними системами»

(C) Собченко T.
} 
Електронне наукове фахове видання «Адаптивне управління: теорія і практика. Серія «Педагогіка» Випуск 9(17), 2020

форму навчання усі студенти були заведені на дистанційну платформу MOODLE. На Рис.1 представлено сторінку особового кабінету викладача Собченко Т.М.

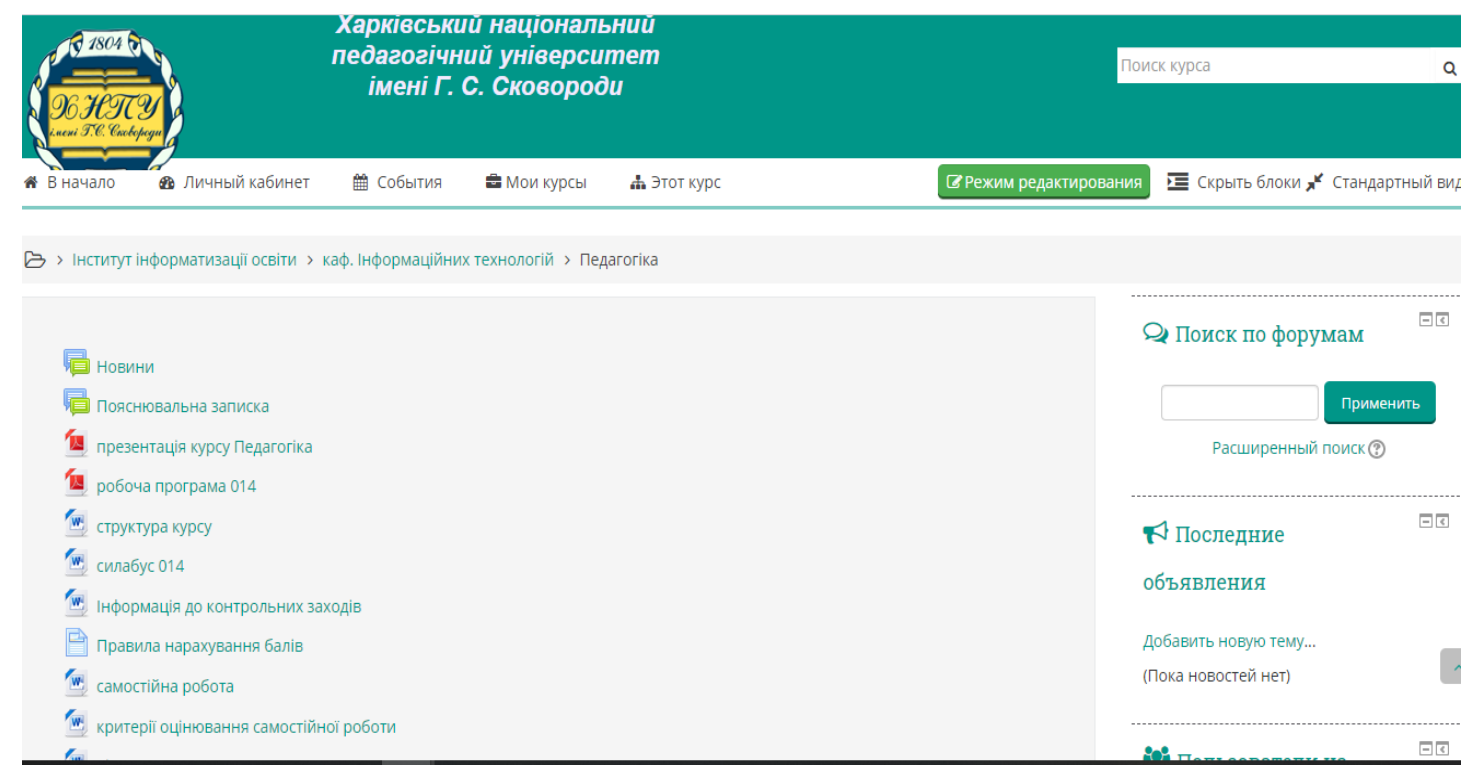

Рис.1. Сторінка особового кабінету на дистанційній платформі MOODLE

Для студентів було розміщено всю необхідну інформацію для вивчення навчальної дисципліни «Педагогіка», а саме: пояснювальну записку, інструктаж, структуру курсу, робочу програму, силабус, тощо.

Лекційні заняття проводилися у режимі онлайн на платформах Google Meet, Zoom, а також зміст лекції було виставлено у вигляді презентації, тез, відеоконтенту у курсі «Педагогіка» на платформі MOODLE, що дозволило здобувачам ознайомлюватися 3 матеріалами у зручному для них режимі (синхронному чи асинхронному). Обов'язковим для студентів було виконання завдання до лекції, що забезпечувало вірогідність опрацювання теми лекції. Студенти мали змогу бачити термін виконання завдання та розрахувати свій час.

Досить ефективно було організовано проєктну роботу за допомогою сервісу Padlet. Таким чином були опрацьовані теми «Принципи навчання»,
(C) Українська інженерно-педагогічна академія
(C) ГО «Школа адаптивного управління соціально-педагогічними системами»
(C) Собченко Т. 
Електронне наукове фахове видання «Адаптивне управління: теорія і практика. Серія «Педагогіка»

Випуск 9(17), 2020

«Методика проведення батьківських зборів», «Зміст освіти». Організація групової (проєктної) роботи дозволила студентам розкрити творчі та креативні здібності, можливість проявити свої знання, вміння, навички. Окрім групових проєктів, було запропоновано індивідуальні, для того, щоб студент комфортно себе почував та мав змогу обрати для себе зручну форму роботи. На Рис. 2 представлено результати проєкту «Сучасні батьківські збори».

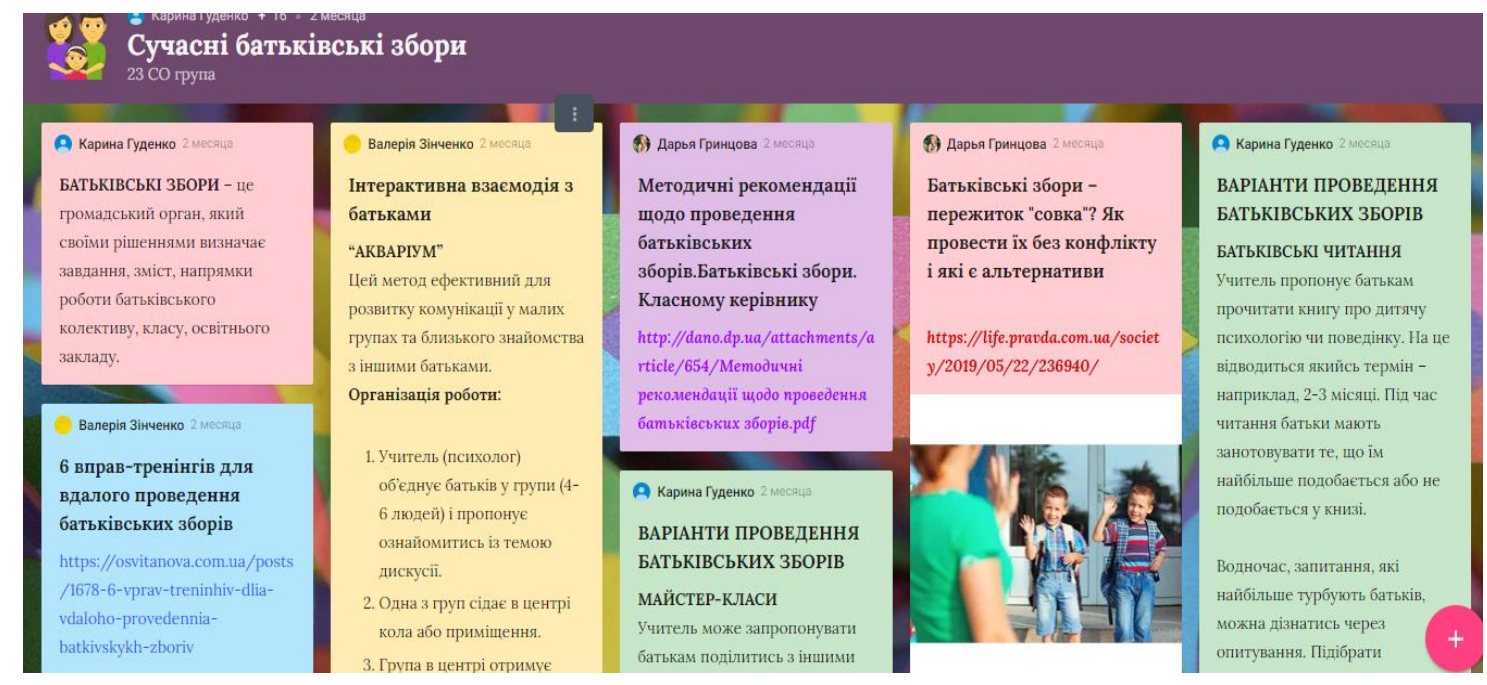

Рис.2. Дошка Padlet проєкт 23 СО групи

Слід зазначити, що нами були проведені опитування здобувачів щодо виявлення проблем (барєрів, перешкод) для них у організації змішананого навчання, які показали, що більшості комфортною є саме така організація навчання. Досить цікавими виявилися деякі обгрунтування, наприклад: «все встигаю», «маю доступ до матеріалів та можливість їх переглядати необхідну кількість разів», «індивідуальний темп навчання», «це набагато цікавіше», «маю більше технічних можливостей» тощо.

Організація змішаного навчання здійснювалась 3 використанням моделі «Перевернутий клас» та «Ротація за станціями», що теж виявилося ефективним під час вивчення тем з педагогіки. Наприклад, опрацьовуючи самостійно тему «STEM OCBITA» здобувачі мали підготувати інфографіку та презентувати іiі або безпосередньо на занятті, або прикріпити виконання цього завдання у

\footnotetext{
(C) Українська інженерно-педагогічна академія

() ГО «Школа адаптивного управління соціально-педагогічними системами»

(C) Собченко Т.
} 
Електронне наукове фахове видання «Адаптивне управління: теорія і практика. Серія «Педагогіка» Випуск 9(17), 2020

MOODLE, що дало змогу здійснити індивідуальний підхід. На Рис.3 фрагмент семінарського заняття.

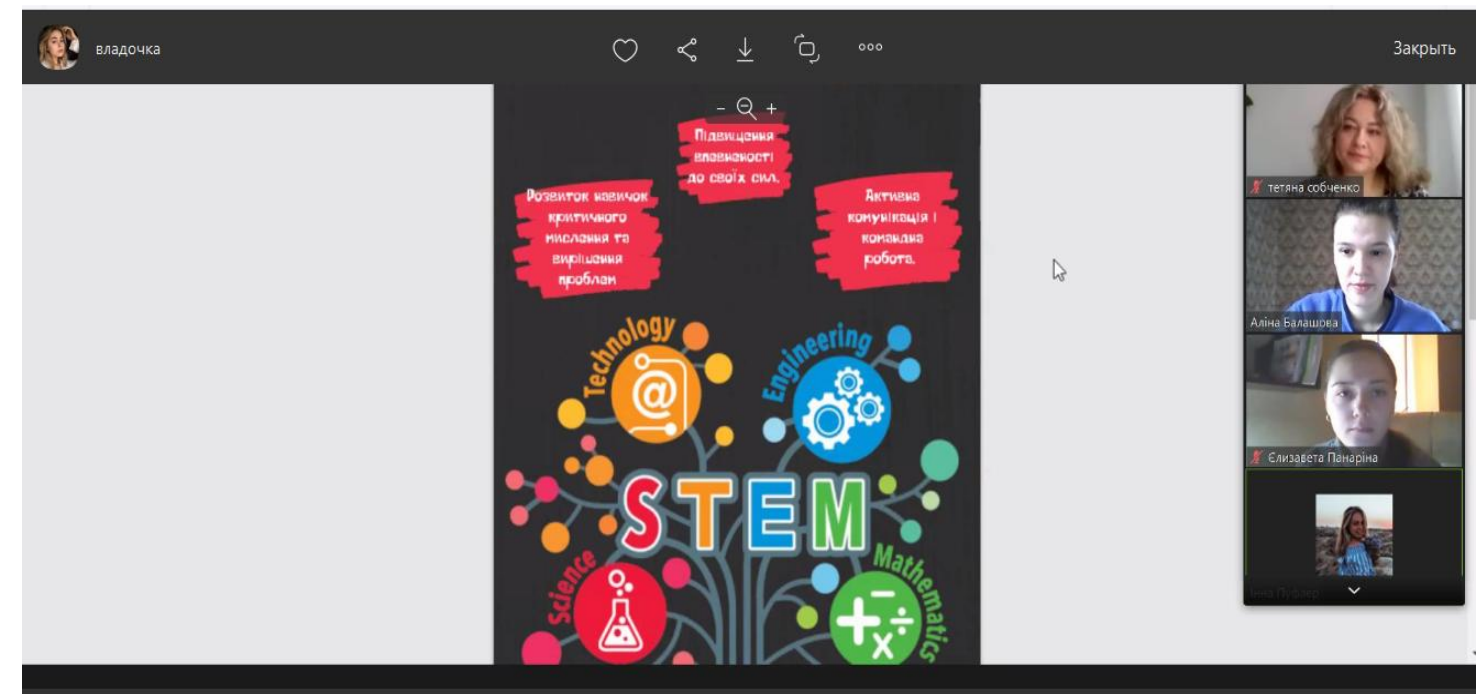

Рис.3. Фрагмент заняття у ZOOM (презентація інфографіки) 21 Ф група

Дуже важливим у змішаному навчанні для активізації адаптивних процесів є організація майданчику для зворотного зв'язку. Це було забезпечено через: електронну пошту, груповий чат Viber, Telegram, чат у MOODLE, соціальні мережі тощо.

Особливе значення відводиться організації контролю навчальнопізнавальної діяльності здобувачів вищої освіти. Для організації поточного контролю ми використовували Інтерактивні робочі листи, Google форми, тестові завдання за допомогою сервісу Kahoot, тести, створені на платформі «На урок» та «Всеосвіта» 3 наданням QR коду, різнорівневі тестові завдання у MOODLE, тощо. Доречі, досить продуктивним було проведення семінарського заняття «Контроль навчально-пізнавальної діяльності учнів». Студентам було запропоновано проаналізувати види організації поточного контролю як традиційного так і створеного за допомогою різних сервісів (попередньо академічні групи мали досвід проведення контролю викладачем). Майбутні вчителі у формі дискусії обговорювали недоліки та переваги проведення кожного виду контролю. Щодо проведення підсумкового контролю, студенти

(C) Українська інженерно-педагогічна академія

(C) ГО «Школа адаптивного управління соціально-педагогічними системами»

(C) Собченко Т. 
Електронне наукове фахове видання «Адаптивне управління: теорія і практика. Серія «Педагогіка»

Випуск 9(17), 2020

за допомогою сервісу Canva готували відеопрезентацію (скринкасти) по вивченим модулям. На Рис.4 представлено фрагмент проведення модульного контролю.

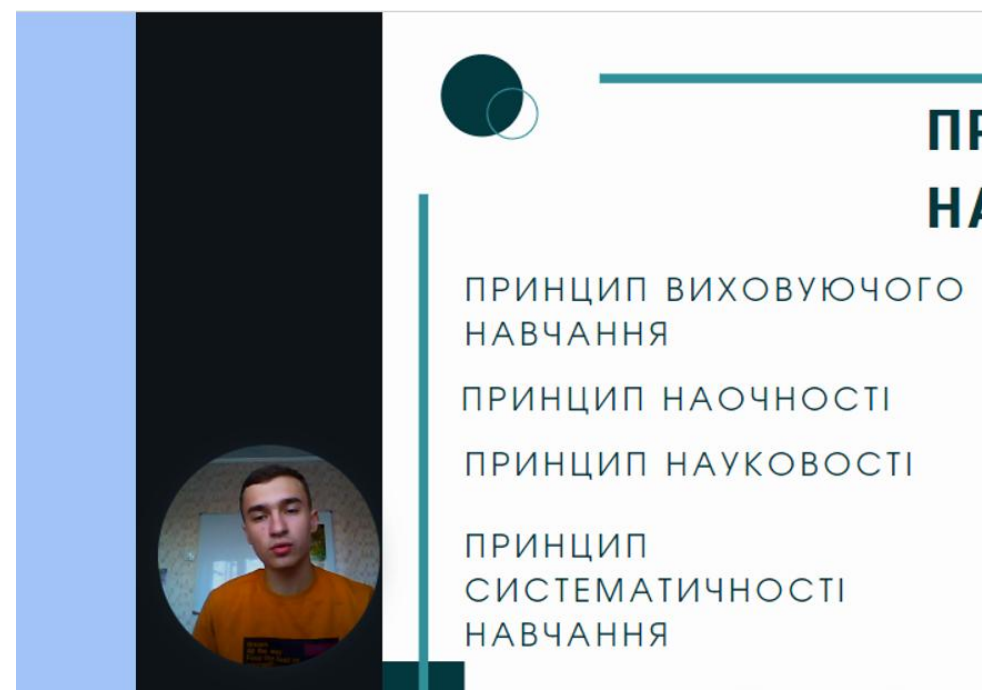

\section{ПРИНЦИПИ НАВЧАННЯ}

Рис.4. Сервіс Canva модульний контроль (модуль «Дидактика»)

Також досить ефективним виявилося використання платформи Trello, де студенти розміщували виконання своїх завдань, та, на відміну від інших сервісів, мали змогу ділитися інформацією один з одним, коригувати та вносити зміни, виконувати групові проєкти ( як на Padlet), отримувати відразу зворотній зв'язок, тощо. Зручний та зрозумілий інтерфейс дав можливість знайти переваги цього сервісу як для студентів, так і для викладача. На Рис.5 представлено робочу дошку на Trello.

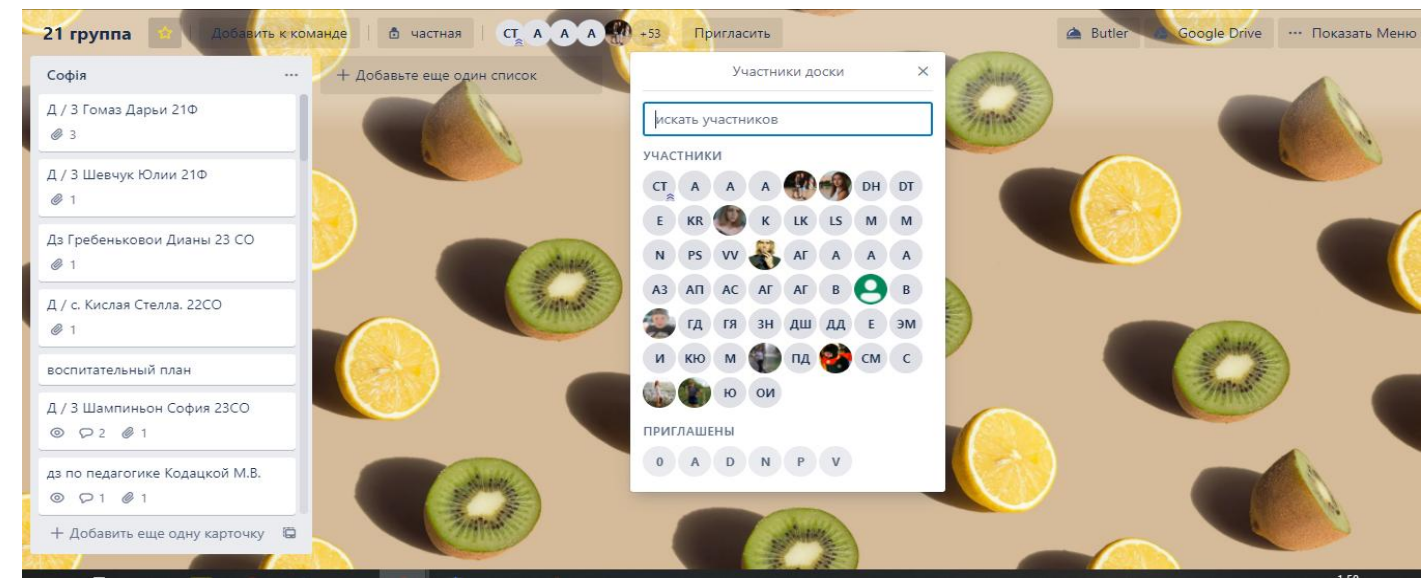

Рис.5 Робоча дошка Trello

(C) Українська інженерно-педагогічна академія

(c) ГО «Школа адаптивного управління соціально-педагогічними системами»

(C) Собченко T. 
Електронне наукове фахове видання «Адаптивне управління: теорія і практика. Серія «Педагогіка»

Випуск 9(17), 2020

Отже, практичний досвід використання змішаного навчання для активізації адаптивних процесів, свідчить про такі переваги:

- підвищення рівня мотивації до навчання;

- забезпечення зручного темпу навчання (відповідно індивідуальним особливостям);

- поглибленого оволодіння засобами IКТ;

- підвищення рівня формування цифрової компетентності;

- можливість більше часу відводити на вивчення тем підвищеної складності;

- високий рівень оволодіння академічними знаннями 3 дисципліни, про що свідчать результати підсумкового контролю.

Щодо слабких сторін, слід зазначити, недостатньо сформований рівень цифрової грамотності у викладача та здобувачів спонукав одночасно оволодівати сучасними інформаційно-комунікативними та хмарними технологіями та застосовувати їх у навчальному процесі; низька матеріальнотехнічна база закладу освіти, зокрема комп'ютерне оснащення навчальних аудиторій; не однаковий доступ до мережі Інтернет та можливості гаджетів.

Висновки. У процесі дослідження було проаналізовано можливості використання змішаного навчання для активізації адаптивних процесів у вищій педагогічній освіти. Аналіз науково-педагогічної літератури й власного досвіду дав підстави стверджувати, що змішане навчання $є$ дієвим та ефективним засобом для активізації адаптивних процесів у закладах вищої педагогічної освіти, який сприяє здійсненню індивідуального підходу. Також доведено, що використання змішаного навчання $є$ необхідним для вивчення педагогічних дисциплін.

Напрями подальших досліджень. Подальші розвідки досліджень спрямовані на теоретичне обгрунтування дидактичної системи змішаного навчання студентів гуманітарних спеціальностей у закладах вищої педагогічної освіти.

(C) Українська інженерно-педагогічна академія

() ГО «Школа адаптивного управління соціально-педагогічними системами»

(C) Собченко T. 


\section{СПИСОК ЛІТЕРАТУРИ}

1. Адаптивне навчання студентів професії вчителя: теорія і практика: монографія / за заг. ред. В.І. Бондаря. Київ: Вид-во НПУ імені М. П. Драгоманова, 2018. 308 с.

2. Астахова М., Лапко Д. Введение дистанционного обучения в общее среднее образование: адаптация к изменениям. Адаптивное управление: теория u практика. Серия Педагогика,9 (17). 2020. Режим доступу: https://amtp.org.ua/index.php/journal/article/view/260.

3. Бунтури Ю.В., Канищева О.В., Вовк М.А, Лютенко И.В. Адаптивное обучение, как одно из перспективных направлений в современной информационной обучающей системе Інформаційні технологї в економіці, екології, медиџині та освіті. 2017. С.155-162.

4. Сльникова Г. В. Адаптивні технології в освіті. Адаптивне управління: теорія і практика. Серія "Педагогіка". № 3 (5). 2017 [Електронний ресурс]. Режим доступу: http://am.eor.by/images/adapt/Vol.3ped5/17ped3_5yelnikova_r.

5. Сльникова Г. В. СТЕМ-ОСВІТА в контексті адаптивного підходу [Електронний ресурс]. - Режим доступу: https://www.researchgate.net/publication/328769066_STEMOSVITA V KONTEKSTI ADAPTIVNOGO PIDHODU

6. Концепція розвитку педагогічної освіти. Режим доступу: https://mon.gov.ua/ua/npa/pro-zatverdzhennya-koncepciyi-rozvitku-pedagogichnoyiosviti

7. Опалюк Т.Л. Адаптивне навчання студентів та його структура. Наук. зап. Терноп. наи. пед. ун-ту. Сер. Педагогіка. 2014.№ 2. С. 58-62.

8. Пішванова В.О. Принципи адаптивного навчання. Педагогічні науки: Вісник Запорізького національного університету. 2015. № 1 (24). С. 178-183.

9. Собченко Т.М. Підготовка майбутніх педагогів до інноваційної професійної діяльності. Збірник наукових пращь «Педагогіка та психологія». Харків. 2020. Вип. 63. С.159-167.

10. Цвєтаєва О., Знанецька О. Адаптивне навчання в сучасній системі освіти Зб. наук. праџь ДНУ імені Олеся Гончара. Педагогічні науки. 2019. № 87, C. 170-175.

\section{REFERENCES}

1. Adaptyvne navchannia studentiv profesii vchytelia: teoriia i praktyka [Adaptive learning of students of the teaching profession: theory and practice]: monohrafiia / for general. ed. V.I. Bondar. Kyiv: Drahomanov National Pedagogical

\footnotetext{
(C) Українська інженерно-педагогічна академія

(C) ГО «Школа адаптивного управління соціально-педагогічними системами»

(C) Собченко T.
} 
University Publishing House, 2018. 308 s.

2. Astahova M., Lapko D. Vvedenie distantsionnogo obucheniya $\mathrm{v}$ obschee srednee obrazovanie: adaptatsiya $\mathrm{k}$ izmeneniyam. [Introduction of distance learning in general secondary education: adaptation to change]. Adaptive control: theory and practice. Pedagogy series, 9 (17). 2020. URL: https://amtp.org.ua/index.php/journal/article/view/260.

3. Bunturi Yu.V., Kanischeva O.V., Vovk M.A, Lyutenko I.V. Adaptivnoe obuchenie, kak odno iz perspektivnIh napravleniy $\mathrm{v}$ sovremennoy informatsionnoy obuchayuschey sisteme. [Adaptive learning as one of the promising areas in the modern information training system]. Information technology in economics, ecology, medicine and education. 2017. S.155-162.

4. Ielnykova H. V. Adaptyvni tekhnolohii v osviti. [Adaptive technologies in education]. Adaptive control: theory and practice. Series "Pedagogy". № 3 (5). 2017. URL: http://am.eor.by/images/adapt/Vol.3ped5/17ped3_5yelnikova_r

5. Yelnykova H. V. STEM-OSVITA $v$ konteksti adaptyvnoho pidkhodu. [STEM EDUCATION in the context of an adaptive approach]. URL: https://www.researchgate.net/publication/328769066_STEMOSVITA_V_KONTEKSTI_ADAPTIVNOGO_PIDHODU

6. Kontseptsiia rozvytku pedahohichnoi osvity. [The concept of development of pedagogical education]. URL: https://mon.gov.ua/ua/npa/pro-zatverdzhennyakoncepciyi-rozvitku-pedagogichnoyi-osviti

7. Opaliuk T.L. Adaptyvne navchannia studentiv ta yoho struktura. [Adaptive learning of students and its structure]. Science. zap. Ternopil. nat. ped. un-tu. Ser. Pedagogy 2014. № 2. S. 58-62.

8. Pishvanova V.O. Pryntsypy adaptyvnoho navchannia. [Principles of adaptive learning]. Pedagogical sciences: Bulletin of Zaporizhia National University 2015. № 1 (24). S. 178-183.

9. Sobchenko T.M. Pidhotovka maibutnikh pedahohiv do innovatsiinoi profesiinoi diialnosti. [Preparation of future teachers for innovative professional activity]. Collection of scientific works "Pedagogy and Psychology". Kharkiv. 2020. Vip. 63. S.159-167.

10. Tsvietaieva O., Znanetska O. Adaptyvne navchannia v suchasnii systemi osvity. [Adaptive learning in the modern education system] Sat. Science. works of Oles Honchar DNU. Pedagogical sciences. 2019. № 87, S. 170-175.

\footnotetext{
(C) Українська інженерно-педагогічна академія

(C) ГО «Школа адаптивного управління соціально-педагогічними системами»

(C) Собченко Т.
} 
Електронне наукове фахове видання «Адаптивне управління: теорія і практика. Серія «Педагогіка»

Випуск 9(17), 2020

\author{
СОБЧЕНКО ТАТЬЯНА, \\ кандидат педагогических наук, \\ доцент, \\ доцент кафедры педагогики \\ Харьковского национального \\ педагогического \\ университета имени \\ Г.С. Сковороди, \\ г. Харьков, Украина,
}

\title{
СМЕШАННОЕ ОБУЧЕНИЕ КАК СРЕДСТВО АКТИВИЗАЦИИ АДАПТИВНЫХ ПРОЦЕССОВ В ВЫСШЕМ ПЕДАГОГИЧЕСКОМ ОБРАЗОВАНИИ
}

Аннотация. Статья посвящена организации смешанного обучения в учреждениях высшего педагогического образования. Акцентировано внимание на возможностях реализации смешанного обучения как средства активизации адаптивных процессов в высшем педагогическом образовании.

Отмечено, что активизация адаптивных процессов является достаточно востребованной в настоящем времени. В статье проведен анализ работ отечественных и зарубежных ученых из определенной проблемы исследования.

В содержании статьи представлен собственный опыт организации смешанного обучения на примере изучения педагогических дисциплин будущими учителями-филологами в Харьковском национальном педагогическом университете имени Г.С. Сковороды и раскрывается его адаптивный характер. Рассматриваются способы организации образовательного контента, создание дифференцированных задач, осуществления активизации учебно-познавательной деятельности и мотивации студентов. Внимание сосредоточено также на организации различных видов контроля (текущего, итогового) учебно-познавательной деятельности, как важной составляющей адаптивного процесса обучения.

Обращено внимание на то, еще в организации смешанного обучения важным моментом является выбор моделей. Модели «Перевернутого класса», «Ротации за станциями» являются наиболее удобными и целесообразными при преподавании педагогических дисциплин.

В статье приводятся конкретные примеры использования информационно-коммуникативных и облачных технологий в процессе изучения педагогических дисциплин соискателями гуманитарных специальностей.

Обобщено возможности смешанного обучения как средства активизации адаптивных процессов в высшем педагогическом образовании, в частности это
(C) Українська інженерно-педагогічна академія
(C) ГО «Школа адаптивного управління соціально-педагогічними системами»
(C) Собченко Т. 
Електронне наукове фахове видання «Адаптивне управління: теорія і практика. Серія «Педагогіка»

реализация индивидуального подхода к личности соискателя, а также определены его преимущества и слабые стороны.

Отмечено, что дальнейшие разведки исследований будут касаться обоснований дидактической системы смешанного обучения студентов гуманитарных специальностей в учреждениях высшего педагогического образования.

\section{SOBCHENKO TETYANA,}

Ph.D. in Pedagogy, Associate Professor, Head of the Department of pedagogy,

H.S. Skovoroda Kharkiv National Pedagogical University,

Alchevskykh Street 29, Kharkiv, Ukraine, E-mail: sobchenkotetyana79@gmail.com

\section{MIXED LEARNING AS A MEANS OF ACTIVATING ADAPTIVE PROCESSES IN HIGHER PEDAGOGICAL EDUCATION}

Abstract. The article is devoted to the organization of blended learning in institutions of higher pedagogical education. Emphasis is placed on the highlighted opportunities for the implementation of blended learning as a means of activating adaptive processes in higher pedagogical education.

It is noted that the intensification of adaptive processes is currently in demand today. The article analyzes the works of domestic and foreign scientists on the identified research problem.

The article presents his own experience of organizing blended learning on the example of the study of pedagogical disciplines by pre-service teachers of philology at Kharkiv National Pedagogical University named after G.S. Skovoroda and reveals its adaptive nature. Were considered the ways of organization of educational content, creation of differentiated tasks, implementation of activation of educational and cognitive activity and motivation of students. Attention is also focused on the organization of various types of control (current, final) educational and cognitive activities, as an important component of the adaptive learning process.

Attention is paid to the fact that even in the organization of blended learning an important point is the choice of models. Models of "Inverted class", "Rotation by stations" are the most convenient and appropriate in the teaching of pedagogical disciplines.

The article provides specific examples of the use of information and communication and cloud technologies in the study of pedagogical disciplines by applicants for humanities.

The possibilities of blended learning as a means of activating adaptive processes in higher pedagogical education are generalized, in particular, the

(C) Українська інженерно-педагогічна академія

(C) ГО «Школа адаптивного управління соціально-педагогічними системами»

(C) Собченко T. 
Електронне наукове фахове видання «Адаптивне управління: теорія і практика. Серія «Педагогіка» Випуск 9(17), 2020

implementation of an individual approach to the applicant's personality, the advantages and weaknesses are identified.

It is noted that further research will relate to the rationale for the didactic system of blended learning of humanities students in higher pedagogical education.

Keywords. Blended learning, adaptive learning, applicants for higher education, pedagogical disciplines. 